\title{
(RE)ESTRUTURAÇÃO URBANA E DESIGUALDADES SOCIOESPACIAIS EM REGIÃO E CIDADE DO AGRONEGÓCIO
}

\author{
RENATO PEQUENO ${ }^{1}$ \\ DENISE ELIAS ${ }^{2}$ \\ Universidade Federal do Ceará \\ Universidade Estadual do Ceará
}

\begin{abstract}
Resumo: No presente artigo apresentamos resultados de pesquisa cujo problema central foi melhor compreender algumas das características da urbanização brasileira inerentes à difusão do agronegócio globalizado. Como objetos principais de análise tivemos as cidades de Barreiras e Luís Eduardo Magalhães (BA), que exercem centralidade urbana de ampla região produtiva do agronegócio de grãos nos Cerrados nordestinos. Entre as hipóteses trabalhadas estava a do acirramento das desigualdades socioespaciais na escala intraurbana, porquanto, de maneira geral, nas áreas onde o agronegócio globalizado se difunde, acirra-se a concentração das riquezas geradas. Para trabalhar a hipótese supracitada selecionamos a produção da moradia como variável-chave, por entender que é na construção dos espaços residenciais que é possível perceber a forma mais predatória da urbanização brasileira recente. A despeito de reconhecermos as interseções derivadas de associações entre os diferentes agentes produtores do espaço urbano, adotando as formas como a moradia se configura na paisagem, a nosso ver, teríamos a sobreposição de três cidades nos espaços intraurbanos: a) a cidade derivada das políticas públicas; b) a cidade do mercado imobiliário; e c) a cidade informal. As constatações às quais chegamos sinalizam a segregação residencial e a fragmentação socioespacial como macrodinâmicas capazes de explicar a estruturação das cidades, evidenciando ainda o
\end{abstract}

\footnotetext{
${ }^{1}$ Professor do Departamento de Arquitetura e Urbanismo da Universidade Federal do Ceará (UFC). Arquiteto graduado em Arquitetura e Urbanismo pela Universidade de São Paulo (1991), Mestrado em Planejamento de Infraestruturas pela Universitat Stuttgart (1995) e Doutorado em Arquitetura e Urbanismo pela Universidade de São Paulo (2002). Contato: renatopequeno@gmail.com.

2 Professora do Programa de Pós-Graduação em Geografia da Universidade Estadual do Ceará (UECE). Geógrafa e doutora em Geografia Humana pela Universidade de São Paulo (1996). Contato: deniseliasgeo@gmail.com.
} 
acirramento das desigualdades entre os diferentes grupos sociais. A análise dos resultados recentes do Programa Minha Casa Minha Vida nestas cidades, tratando-se dos seus arranjos institucionais e das condições de inserção urbana, também é esclarecedora. Observa-se, ainda, a fragilidade institucional destes municípios, tendo em vista o enfrentamento dos problemas relacionados às más condições de moradia e às disfunções urbanas.

Palavras-chave: Agronegócio Globalizado; Desigualdades Socioespaciais; Região Produtiva do Agronegócio; Moradia; Programa Minha Casa Minha Vida; Barreiras; Luís Eduardo Magalhães.

\section{URBAN (RE)STRUCTURING AND SOCIO-SPATIAL INEQUALITIES IN THE REGION AND IN THE CITY OF AGRIBUSINESS}

Abstract: In this article we present some results of a research whose main objective was to better understand some characteristics of Brazil's urbanization and its ties to the spread of globalized agribusiness. The analysis focused on the cities of Barreiras and Luís Eduardo Magalhães (BA), key urban centralities in an extensive area of grain production in the Cerrado of Brazil's northeast. Among the hypotheses considered was that of an increase in sociospatial inequalities in the urban space, because in areas where globalized agribusiness expanded, the concentration of wealth has typically increased. To examine the abovementioned hypothesis, we selected housing supply as a key variable, since we understand that through the construction of residential settlements we can observe how predatory Brazil's recent urbanization has been. Despite recognizing the intersections that result from associations between the different social actors in the urban space, by examining how the housing stock shaped landscapes, we can distinguish an overlap of three cities in the intraurban space: a) the city of the real estate market; b) the informal city; and c) the city derived from public policies. Our findings suggest that residential segregation and socio-spatial fragmentation are the outcomes of macro-dynamics that explain the structure of cities, shedding light on the growth of spatial inequalities among different social groups. The analysis of the recent results of the Minha Casa Minha Vida Program in these cities, including their institutional arrangements and their location in the urban space, are also instructive. The institutional fragility of these municipalities is also highlighted,given the problems arisingfrompoor housing conditions and urban dysfunctions and the way these were tackled.

Keywords: Agribusiness Globalized; Socio-Spatial Inequalities; Housing; Program Minha Casa Minha Vida; Barreiras; Luís Eduardo Magalhães.

\section{Introdução}

Neste artigo apresentamos resultados de pesquisa cujo problema central foi melhor compreender algumas das características da urbanização brasileira inerentes à difusão do agronegócio globalizado (SANTOS, 1993, ELIAS, 2003) em ampla região produtora de grãos nos Cerrados do Nordeste brasileiro, especialmente considerando os processos inerentes às novas dinâmicas de (re)produção dos espaços agrícolas e urbanos ${ }^{3}$.

Entre as hipóteses trabalhadas estava a do acirramento das desigualdades socioespaciais na escala intraurbana. Porquanto, de maneira geral, nas áreas onde o agronegócio globalizado se difunde, campo e cidade são transformados ao sabor de

\footnotetext{
${ }^{3}$ Projeto de pesquisa intitulado Economia Política dos Territórios do Agronegócio no Brasil, que contou com o apoio do MCT/ CNPq, edital Universal.
} 
uma racionalidade excludente e, concomitantemente ao crescimento econômico, acirra-se a concentração das riquezas geradas.

Como objetos de análise para o presente texto tivemos as cidades baianas de Barreiras e Luís Eduardo Magalhães (LEM), que polarizam o que Elias (2006c; 2011; 2013) chama de Região Produtiva do Agronegócio (RPA) de grãos, notadamente soja, em franca expansão desde os anos 1990.

Para trabalhar a hipótese supracitada, selecionamos a produção da moradia como variável-chave, pois no nosso entendimento e de acordo com Pequeno (2010), é na construção dos espaços residenciais que se perceberá a forma mais predatória da urbanização no Brasil nas últimas décadas.

A despeito de reconhecermos as interseções derivadas de associações entre os diferentes agentes produtores do espaço urbano, adotando as formas como a moradia se configura na paisagem enquanto referência poderíamos confirmar a existência da sobreposição de três cidades nos espaços intraurbanos, a saber: a) a cidade produzida pelo mercado imobiliário - na qual promotores imobiliários, incorporadores, construtores e corretores realizam a produção capitalista do espaço -; b) a cidade onde a moradia é produzida de maneira espontânea e informal com realce para o processo de favelização, destacando-se as áreas de ocupação nas quais o próprio morador toma a frente do processo construtivo sem qualquer assistência técnica; e c) a cidade derivada das políticas públicas de desenvolvimento urbano e habitacional, com a produção de habitação de interesse social e a formulação dos processos de planejamento na qual o Estado sobressai como agente principal.

Essa classificação corresponde a um recurso metodológico elaborado por Pequeno (PEQUENO; ELIAS, 2010) com objetivo de agrupar as dinâmicas socioespaciais nas quais se observa a predominância e o protagonismo de determinados agentes, sem, no entanto, significar a exclusão dos demais. Além disso, não se trata de um modelo replicável a todas as cidades que realizam a gestão de RPA, mas de um conjunto de aspectos que as caracterizam e podem ser qualificados graças às especificidades inerentes a cada uma das cidades e regiões em que estas se localizam.

Para a consecução da pesquisa utilizamos notadamente a metodologia qualitativa, com a realização de pesquisa bibliográfica, documental e em jornais eletrônicos; o levantamento e a organização de dados estatísticos do IBGE e da Fundação João Pinheiro. E também fontes de dados secundários, enfatizando como imprescindíveis os trabalhos de campo realizados não só em Barreiras e LEM, como em vários outros municípios que, a nosso ver, também pertencem à mesma RPA gestada por estas duas cidades, estando localizados não só na Bahia, mas também nos estados do Piauí, Maranhão e Tocantins. ${ }^{4}$

\footnotetext{
${ }^{4}$ Cidades nas quais realizamos trabalho de campo em diferentes momentos: do oeste da Bahia: Correntina, São Desidério, Riachão das Neves e Formosa do Rio Preto; Balsas, no sul do Maranhão; Uruçuí no sul do Piauí. Vale destacar que nosso primeiro trabalho de campo por esses municípios se
} 
Os trabalhos de campo visaram, especialmente, entrevistas semiestruturadas e pequenos colóquios com representantes das instituições públicas, movimentos sociais, empresas hegemônicas associadas ao agronegócio, sindicatos patronais e de trabalhadores, representantes de organizações não governamentais, pesquisadores das universidades (em especial do curso de Geografia da UFOBA), engenheiros responsáveis pelas obras do Programa Minha Casa Minha Vida (PMCMV) etc; o levantamento de informações junto às prefeituras e secretarias municipais, tais como da legislação urbana das cidades estudadas (Plano Diretor, Lei de Zoneamento, Código de Obras, Lei do Perímetro Urbano); visitas técnicas aos canteiros de obras do PMCMV nas cidades de Barreiras e LEM; conversas informais com moradores da periferia destas cidades; vivência do cotidiano das cidades visitadas, considerando fixos e fluxos etc.

Além desta introdução e das considerações finais, o artigo se encontra dividido em quatro itens. No primeiro apresentamos as bases da relação entre a difusão do agronegócio globalizado, o incremento da urbanização e de novas regionalizações, evidenciando, assim, os fundamentos da (re)estruturação das cidades estudadas. Em seguida tratamos da estruturação das cidades segundo sua rede viária regional, assim como das condições de moradia com base nos dados dos Censos Demográficos, referenciados no total de domicílios permanentes urbanos. Posteriormente apresentamos, num esforço de síntese, algumas dinâmicas socioespaciais que caracterizam a produção do espaço urbano em Barreiras e LEM, especialmente a partir das escolhas locacionais efetuadas pelos três principais agentes da produção da moradia considerados para análise: os associados ao mercado imobiliário, à cidade informal e às políticas públicas. O Programa Minha Casa Minha Vida é tema do item subsequente.

\section{Agronegócio, urbanização, regionalização e (re)estruturação urbana}

A tese que sustentou a pesquisa ora relatada foi a de que a reestruturação produtiva da agropecuária, que atinge tanto a base técnica quanto a econômica e social do setor - e que está na base da difusão do agronegócio globalizado repercute não só sobre os espaços agrícolas, como também promove e intensifica vários outros processos, tais como o da urbanização, da intensificação das relações campo-cidade, da produção de espaço urbano, da (re)estruturação da cidade, do

deu em 2004, quando da realização de uma outra pesquisa. Os mais recentes se realizaram em 2012 e em 2014. 
aumento das desigualdades socioespaciais, assim como induz a novas regionalizações 5 .

A base para tais explicações está na intensificação da apropriação capitalista da agricultura, com significativo incremento da agricultura empresarial apoiada em um modelo técnico, econômico e social de produção globalizada - oferecendo novas possibilidades para a acumulação ampliada do capital - ao qual chamaremos aqui de agronegócio globalizado (SANTOS, 1993; ELIAS, 2003). Caracteriza-se, desde então, uma nova organização da agropecuária que acompanha a unificação da economia pelo movimento do capital industrial e financeiro.

Isso indica, entre outras, significativas mudanças das formas de uso e ocupação do espaço agrícola, com o acirramento da privatização do acesso à terra e à água e, consequentemente, da concentração fundiária, o que promove a expulsão e expropriação dos pequenos agricultores, que passam a residir nas cidades; as mudanças dos sistemas técnicos agrícolas com uma gama de novas demandas de produtos e serviços que aumentam o número de casas comerciais e a prestação de serviços associados ao consumo produtivo (SANTOS, 1993) das empresas agrícolas e agroindustriais nas cidades próximas e, consequentemente, reorganizam a economia urbana destas (ELIAS, 2003; ELIAS; PEQUENO, 2010).

Ao mesmo tempo tais processos promoveram intensa migração de mão de obra especializada para essas cidades (agrônomos, veterinários, técnicos agrícolas etc.), em grande parte oriunda de cidades maiores de várias partes do país. Estes processos efetivamente estão na base do crescimento da urbanização, do número e do tamanho das cidades em várias partes do Brasil onde se processa a difusão do agronegócio globalizado.

Da mesma forma, estão no cerne da formação de novas regionalizações, as quais Elias (2006c; 2011; 2012; 2013) denomina de Regiões Produtivas do Agronegócio (RPA). Estas seriam verdadeiros híbridos compostos tanto por modernos espaços agrícolas extremamente racionalizados quanto por espaços urbanos não metropolitanos (sobretudo cidades pequenas, mas também cidades de porte médio), com forte especialização funcional. Formam nós, pontos ou manchas das redes agroindustriais (ELIAS, 2008) e são perpassadas por parte dos circuitos espaciais de produção e círculos de cooperação (SANTOS, 1988, 1993) de commodities ou outras importantes produções agropecuárias, os quais evidenciam as dinâmicas territoriais do agronegócio globalizado. São, assim, as áreas detentoras dos mais expressivos investimentos produtivos inerentes a este setor, representando suas regiões mais especializadas e competitivas.

As RPAs constituem lugares propícios ao exercício dos capitais hegemônicos porquanto apresentam muitas novas possibilidades para a acumulação ampliada do capital do agronegócio, sejam por suas formas mais clássicas ou pelas novas

\footnotetext{
${ }^{5}$ Essa tese já foi defendida e trabalhada por Denise Elias em vários de suas pesquisas, a começar em sua tese de doutorado, defendida em 1996 e publicada alguns anos mais tarde (ELIAS, 2003).
} 
formas mais associadas à financeirização ${ }^{6}$. Assim, as grandes empresas agropecuárias e agroindustriais, como as importantes corporações e as holdings, estão entre os principais agentes produtores do espaço agrícola, urbano e regional em uma RPA, exercendo forte influência na configuração de uma urbanização corporativa (SANTOS, 1993; ELIAS, 2003).

Enquanto o dinamismo econômico associado ao agronegócio globalizado promove rápido e complexo incremento à divisão social e territorial do trabalho, paralelamente às metamorfoses do espaço agrícola temos crescimento da produção do espaço urbano e da (re)estruturação das cidades.

Internamente à RPA observa-se, tal como Corrêa (2006), a existência de hierarquia urbana e especialização funcional. Na nossa percepção, então, podemos falar de uma rede urbana regional funcional ao agronegócio. Nesta, a centralidade urbana, econômica e política é, em muitos casos, exercida por uma cidade de porte médio. Por vezes ocorrem alterações em relação à centralidade urbana exercida na escala regional, sendo frequentes as transferências de liderança entre as cidades.

Ao pensar em tais processos para a área considerada na análise, diríamos termos nos Cerrados nordestinos uma RPA, importante produtora de grãos (especialmente soja) comandada de forma oligopsônica pelas multinacionais Cargill e Bunge, em especial, e mais recentemente também pela ADM, Amaggi\& LCD e Multigran, entre outras ${ }^{7}$.

Entre as conclusões da pesquisa no tocante à hierarquia urbana e aos papéis desempenhados pelas cidades nesta RPA, pensamos que, hoje, duas cidades exercem forte centralidade: Barreiras e Luís Eduardo Magalhães. Ainda que a realização de uma comparação entre as duas não seja o nosso objetivo, vale aqui destacar algumas de suas características que ressaltam suas diferenças e suas complementaridades.

Historicamente Barreiras é a "capital" do oeste baiano e ainda na década de 1980 foi a primeira que despontou como tendo a economia atrelada ao agronegócio da soja no Nordeste (SANTOS FILHO, 1988). Luís Eduardo Magalhães desponta como nova centralidade urbana na região duas décadas mais tarde, seu território originalmente fazia parte do município de Barreiras e foram exatamente o aumento

\footnotetext{
${ }^{6}$ Para mais informações sobre as Regiões produtivas do agronegócio pode ser visto, em especial, Elias, 2011. Sobre uma proposta metodológica para o estudo de uma RPA ver Elias, 2013.

7 A Cargill e a Bunge são algumas das mais importantes multinacionais atuantes no setor do agronegócio em todo o mundo. A Bunge é a principal empresa na industrialização de soja e líder na comercialização de grãos (soja, trigo, milho, sorgo, girassol e semente de algodão) e de óleos vegetais. No Brasil, está presente em dezesseis estados e suas principais plantas industriais na região em estudo estão em Luís Eduardo Magalhães (BA) e Uruçuí (PI). A Cargill encontra-se instalada em Barreiras (BA). Com o incremento da produção e esmagamento de grãos, formaram-se ou chegaram outras poderosas empresas e grupos à região, os quais atuam tanto na produção agrícola quanto na agroindustrial de todo o complexo carne-grãos. Pelo poder que exercem em toda a região, citamos os grupos Horita, Busato, Franciosi, Vanguarda Agro, Coringa, Mauricea Alimentos, Fri-Barreiras, Frango de Ouro, entre outros.
} 
da divisão social e territorial do trabalho e as disputas de poder por parte dos principais agentes do agronegócio na respectiva RPA que promoveram sua emancipação no ano de 2000.

Como já afirmamos em outras oportunidades (ELIAS, 2006c), a emancipação político-administrativa de LEM ao se transformar em município constitui-se resultado das disputas políticas desencadeadas pelos grupos econômicos hegemônicos atuantes na região, reunindo, na sua maioria, capitais não locais (pessoa jurídica e física), nacionais e multinacionais, que se associam para tentar consolidar o próprio território independente de outras forças políticas e econômicas.

Para nós, Barreiras e LEM efetivamente constituem um binômio e exercem juntas a centralidade urbana da RPA da soja nos Cerrados do Nordeste do Brasil. Enquanto Barreiras desempenha papéis clássicos de uma cidade de porte médio, LEM configura-se no que Elias (2006a; 2006b; 2006c; 2007; 2010) chama de cidade do agronegócio. Assim, ambas têm papel de destaque na região e atendem, em diferentes graus, às necessidades mais básicas tanto da população quanto dos principais agentes do agronegócio atuantes regionalmente.

A primeira concentra a maior parte dos comércios e serviços, sobretudo no que concerne ao consumo consumptivo (SANTOS, 1988; ELIAS, 2003) voltado às demandas da população, além de ser a cidade que reúne as sedes das representações dos órgãos estaduais e federais. Dessa forma, por conta da sua história, localização, tamanho e, especialmente, do oferecimento de alguns serviços públicos - como o de saúde e educação - permanece como uma cidade média e já se encontra em estágio mais avançado de urbanização da sociedade e do território ${ }^{8}$.

O município de Luís Eduardo Magalhães, por sua vez, utilizando-nos do que Elias considera como ponto central para a definição de uma cidade do agronegócio - qual seja, a hegemonia das funções de atendimento às demandas do agronegócio globalizado sobre as demais funções exercidas pela cidade, denotando-se forte especialização da economia urbana - sobressai na RPA pelo oferecimento dos mais modernos produtos e serviços demandados pelas atividades agrícolas e agroindustriais intensivas da região. Neste sentido já ultrapassa Barreiras em vários aspectos. Destaca-se, por exemplo, por possuir revendedores autorizados das maiores fabricantes de máquinas agrícolas que atuam no Brasil ${ }^{9}$.

Se, como diz Carlos (2004), a cidade é a materialização das condições gerais de reprodução do capital, a nosso ver LEM é ela própria forma, processo e função (SANTOS, 1985) para a reprodução do capital do agronegócio globalizado e, assim, uma força produtiva para a reprodução deste (ELIAS, 2007). Seria, então, um exemplo emblemático de município criado como resultado das novas formas de

\footnotetext{
${ }^{8}$ Sobre cidades médias podem ser vistos os trabalhos de Maria Encarnação Sposito (2010a; 2010b).

${ }^{9}$ Tais como da John Deere.
} 
uso do território brasileiro inerente à expansão da economia e da sociedade do agronegócio globalizado, determinante para a produção do seu espaço, seja urbano seja agrário.

Em LEM, a relação intrínseca entre o público e o privado, que marca tão fortemente a história e o território do Brasil, também está presente. Ao longo das duas últimas décadas formaram-se importantes redes de poder inerentes ao agronegócio. Entre as de maior destaque mencionamos a Associação dos Agricultores e Irrigantes da Bahia (Aiba), que exerce seu poder de forma corporativa com total influência na economia, na política e na produção do espaço regional.

Num país onde o imbricamento existente entre os poderes econômico e político é recorrente, acostumamo-nos a ter empresários agrícolas como Ministro da Agricultura, Governador de Estado, além de uma das mais influentes bancadas no Congresso Nacional (a ruralista). Por isso pode parecer comum, assim como ocorre em outras cidades do agronegócio, que o atual prefeito de LEM seja também um empresário do agronegócio ${ }^{10}$. Antes disso esteve à frente da Aiba, que ajudou a criar no início dos anos 1990. Esses elementos estão na base da produção de uma urbanização e de uma cidade corporativas (SANTOS, 1993; ELIAS, 2003), com reflexos perversos na estruturação da cidade, que já tem na fragmentação e desigualdade socioespacial uma de suas marcas principais.

Sua dinâmica populacional serve também de exemplo para a situação em curso em LEM, porquanto o ritmo do seu crescimento supera de longe a média nacional, assim como o de Barreiras. Somava cerca de 10 mil habitantes por ocasião da sua emancipação no ano de 2000, 60.105 em 2010 e 76.420 em 2014, de acordo com dados do IBGE ${ }^{11}$. Isso nos dá um crescimento absoluto de 66.420 habitantes (664 $\%)$ para o período. Somente na década de 2000 os números apresentaram um crescimento de 50.105 habitantes $(500 \%)$. Barreiras, por sua vez, passou de 112.409 para 152.208 habitantes no mesmo período, ou seja, seu crescimento foi de 39.799 habitantes (35\%).

Mas, apesar das diversidades entre as duas cidades, é possível identificar vários processos que se repetem em ambas. Estes se relacionam diretamente à forma desigual como se dá o acesso aos benefícios do crescimento econômico e da urbanização, deflagrando-se, assim, um crescimento urbano marcado por desigualdades de diferentes naturezas, especialmente no que se refere às condições de moradia, que serão analisadas nos itens a seguir.

\footnotetext{
${ }^{10}$ Foi eleito prefeito em 2009 e reeleito em 2012.

${ }^{11}$ Censos Demográficos, de 2000 e 2010, e Contagem Populacional, de 2014.
} 


\section{A estruturação das cidades e as condições desiguais de moradia}

No presente item as análises ganham maior especificidade e tratam da estruturação das cidades segundo sua rede viária regional, assim como das condições de moradia, com base nos dados dos Censos Demográficos realizados pelo IBGE referenciados no total de domicílios permanentes urbanos.

Pareceu-nos importante indicarmos, mesmo que brevemente, o papel determinante que as rodovias federais que atravessam a região convergindo para Barreiras tiveram e ainda têm na dinâmica regional, em especial a BR 242 (que interliga o litoral da Bahia, desde Salvador ao Mato Grosso), a BR 020 (de Fortaleza a Brasília) e a BR 135 (desde o Maranhão até Belo Horizonte - MG).

Além disso, estas vias possuem importante papel na estruturação das cidades aqui estudadas, fazendo da linearidade um dos signos do crescimento das respectivas cidades. No caso de Barreiras, entre os motivos de sua maior importância na região está a confluência destas rodovias em seu território. Destacase a BR 242, que a integra ao chamado Chapadão ${ }^{12}$ em direção a LEM, configurando-se como uma verdadeira espinha dorsal do intraurbano de Barreiras, ao atravessá-la de leste a oeste. Já a BR 135, corta o núcleo urbano de Barreiras de norte a sul passando pelo centro parcialmente sobreposta à BR 020. Por sua vez, a BR 020 atravessa a porção setentrional da sede urbana de Barreiras, inicialmente sobreposta à BR 135 para depois unificar-se à BR 242.

Da mesma maneira, em LEM a BR 242 - em parte sobreposta à BR 020 assume o papel de principal eixo urbano. A sobreposição entre elas se desfaz logo após o Centro de LEM, quando a primeira prossegue na direção oeste rumo aos estados de Tocantins e de Mato Grosso e a segunda retoma seu trajeto a caminho de Brasília.

A importância do trecho da BR 242 entre Barreiras e LEM decorre da instalação de algumas das mais importantes empresas da região, tais como a indústria esmagadora da Cargill em Barreiras, o Distrito Industrial de LEM, entre outras. Ao longo da rodovia, em seus trechos intraurbanos, distribuem-se estabelecimentos voltados aos mais diferentes setores da economia, tais como: grandes agroindústrias; comércios e serviços associados seja ao consumo consumptivo, seja ao consumo produtivo (SANTOS, 1993) do agronegócio (ELIAS, 2003; ELIAS; PEQUENO, 2010), dentre outros.

Citando o caso de LEM, especificamente em seu trecho intraurbano, teríamos serviços de hospedagem, comércio de materiais de construção, importantes revendedoras de veículos, máquinas e insumos agrícolas, e mesmo grandes estabelecimentos do setor produtivo, como as indústrias Bunge e Galvane

\footnotetext{
12 Por conta das suas condições geomorfológicas, o oeste baiano tem sua porção ocidental denominada como Chapadão, áreas planas e de maiores altitudes. Suas condições geotécnicas e hidrológicas foram especialmente propícias para a difusão da produção de grãos, habilitando-se à difusão do agronegócio.
} 
Fertilizantes. Com seus portentosos silos e plantas industriais, estas duas indústrias estão localizadas dentro do perímetro urbano principal, junto à área residencial dentre as mais valorizadas da cidade. A Galvani, uma das grandes indústrias de fertilizantes no país, por exemplo, fica em frente ao hotel Saint Louis, o mais bem equipado e caro da cidade. Assim, trazem para a paisagem urbana um diferencial, além de evidenciar a total falta de ordenamento urbano, misturando diferentes formas de uso e ocupação do solo.

Disso sobressaem algumas semelhanças entre as centralidades das duas cidades: por um lado, a concentração de estabelecimentos voltados para o consumo consumptivo (supermercados, lojas de venda de eletrodomésticos, restaurantes etc.) na área central, com crescimento menos intenso; por outro, a distribuição de estabelecimentos que atendem às demandas do consumo produtivo do agronegócio ao longo da rodovia principal (BR 242), em especial no trecho entre os dois municípios.

$\mathrm{Na}$ escala intraurbana essas vias, apesar de promoverem a integração na esfera regional facilitando todos os tipos de fluxos de população e de mercadorias, trazem para estas cidades os problemas decorrentes do intenso fluxo de caminhões, que transportam todo tipo de carga. Diante de tais problemas, a duplicação destas rodovias federais e a implantação de vias locais paralelas se colocam como alternativas aptas a amenizá-los.

Para o caso de Barreiras encontra-se em implantação uma alça de contorno, prevista desde o Plano Diretor Urbano de Barreiras, de 2004, com o intuito de retirar o fluxo pesado da sua área central. Contudo, esta obra encontra resistências dos representantes do setor terciário em virtude da possível redução da demanda proveniente dos viajantes que trafegam naquela direção. Entretanto, os efeitos negativos da passagem diária de centenas de caminhões, associados à precariedade urbanística deste trecho da rodovia, colocam esta alça como alternativa das mais benéficas à qualidade de vida da população.

No caso de LEM a proposta é diametralmente oposta, pois procura-se valorizar a passagem da BR pela cidade, buscando enaltecê-la como lugar do "desenvolvimento" na região, em cuja paisagem despontam torres residenciais e grandes silos de armazenagem de grãos, assim como os comércios e serviços mais modernos atrelados às demandas do agronegócio.

Este processo de estruturação urbana e regional vinculado às rodovias e à localização das atividades produtivas, ao promover a valorização imobiliária de determinados bairros, reflete na distribuição dos diferentes grupos sociais. Disto evidencia-se a condição da segregação espacial como macroprocesso que explica muito da estrutura de tais cidades.

Além da influência das vias regionais na configuração linear e espraiada, vale destacar a crescente demanda habitacional induzindo sobremaneira o crescimento urbano destas cidades. Assim, para explicitar parte da estrutura delas, notadamente no que tange às condições de moradia, utilizamos os dados do Censo Demográfico, 
realizado pelo IBGE para o ano de 2010, referenciados no total de domicílios permanentes urbanos.

A princípio, como aponta a Tabela 1, as iniquidades relativas às condições de moradia são constatadas pelos dados do déficit habitacional urbano e pelo total de domicílios vagos. De maneira geral, Barreiras e LEM apresentam percentuais altos de déficit habitacional, respectivamente de cerca de $15 \%$ e $24 \%$.

Todavia, quando o número de famílias em situação de déficit habitacional urbano é confrontado ao total de domicílios vagos as condições desiguais de acesso à moradia ficam mais evidentes. Em LEM, por exemplo, eram 3.950 famílias sem moradia em 2010, enquanto a cidade possuía 3.119 domicílios vagos. Os dados mostram, então, que o número de domicílios vagos corresponde a cerca de $80 \%$ do déficit habitacional. Percentual praticamente idêntico era encontrado em Barreiras, que possuía 4.133 domicílios vagos e 5.277 famílias sem moradia.

Poderíamos concluir, entre outras coisas, que o crescimento da mercantilização da produção e do acesso à moradia com o predomínio do valor de troca inviabiliza o acesso para parte importante da população aos bens produzidos pelo mercado imobiliário. Baseando-nos em entrevistas realizadas com corretores imobiliários locais, evidencia-se que parte do capital investido neste mercado tem origem nos ganhos oriundos das transferências de renda do campo e dos lucros das atividades do agronegócio, notadamente no caso do município de Luís Eduardo Magalhães.

\begin{tabular}{|c|c|c|c|c|c|}
\hline $\begin{array}{c}\text { Unidade } \\
\text { territorial }\end{array}$ & $\begin{array}{c}\text { Domicílios particulares } \\
\text { permanentes urbanos } \\
\text { (DPPU) }\end{array}$ & $\begin{array}{c}\text { Domicílios } \\
\text { vagos urbanos }\end{array}$ & $\begin{array}{c}\text { \% de domicílios } \\
\text { vagos em relação } \\
\text { ao total de DPPU }\end{array}$ & $\begin{array}{c}\text { Déficit } \\
\text { habitacional } \\
\text { urbano (DHU) }- \\
\text { famílias }\end{array}$ & $\begin{array}{c}\text { \% do déficit } \\
\text { em relação ao } \\
\text { total de DPPU }\end{array}$ \\
\hline Bahia & 3.034 .097 & 383.684 & 12,6 & 388.870 & 12,8 \\
\hline Salvador & 858.277 & 77.731 & 9,1 & 106.385 & 12,4 \\
\hline Barreiras & 34.824 & 4.133 & 11,9 & 5.277 & 15,2 \\
\hline LEM & 16.380 & 3.119 & 19,0 & 3.950 & 24,1 \\
\hline
\end{tabular}

Tabela 1: Déficit habitacional urbano e domicílios vagos urbanos, 2010.

Fonte: Fundação João Pinheiro, com base nos dados do Censo IBGE de 2010.

De acordo com a Fundação João Pinheiro (2014), o déficit habitacional se deve a diferentes fatores associados à falta de moradia: a coabitação familiar - quando famílias compartilham a mesma moradia em razão da sua incapacidade de pagamento de aluguel ou de adquirir a casa própria -; o ônus excessivo com o aluguel para as famílias com renda inferior a três salários mínimos e que despendem $30 \%$ ou mais da renda domiciliar com aluguel; o adensamento excessivo de domicílios alugados, quando há um número médio acima de três pessoas por dormitório; a precariedade do domicílio na forma como foi construído, utilizando materiais rústicos ou em situação improvisada. 
No caso de Barreiras e de Luís Eduardo Magalhães, como exposto na Tabela 2, cerca de $50 \%$ do déficit habitacional se concentrava na coabitação familiar. Em segundo lugar vinham as famílias que comprometiam mais de $30 \%$ de suas rendas para custear o aluguel, com reflexos negativos na qualidade de vida. Juntos estes dois componentes do déficit representam mais de $85 \%$ do total da carência nas duas cidades. A presença de moradias alugadas com adensamento excessivo, por sua vez, é bastante presente em LEM, representando 12,5\% do déficit habitacional urbano e podia ser visto de forma bem evidente nos bairros pobres da cidade.

\begin{tabular}{|c|c|c|c|c|c|c|c|c|}
\hline $\begin{array}{c}\text { Unidade } \\
\text { territorial }\end{array}$ & $\begin{array}{c}\text { Coabitação } \\
\text { familiar } \\
\text { urbana }\end{array}$ & $\begin{array}{c}\% \text { déficit } \\
\text { habitac. } \\
\text { urbano }\end{array}$ & $\begin{array}{c}\text { Ônus } \\
\text { excessivo } \\
\text { com } \\
\text { aluguel }\end{array}$ & $\begin{array}{c}\% \text { do } \\
\text { déficit } \\
\text { habitac. } \\
\text { Urbano }\end{array}$ & $\begin{array}{c}\text { Adensam. } \\
\text { excessivo } \\
\text { domićlios } \\
\text { alugados }\end{array}$ & $\begin{array}{c}\% \text { do } \\
\text { déficit } \\
\text { habitac. } \\
\text { Urbano }\end{array}$ & $\begin{array}{c}\text { Domicílios } \\
\text { precários } \\
\text { urbanos }\end{array}$ & $\begin{array}{c}\% \text { do } \\
\text { déficit } \\
\text { habitac. } \\
\text { Urbano }\end{array}$ \\
\hline Bahia & 198.792 & 51,1 & 124.687 & 32,1 & 19.092 & 4,9 & 46.299 & 11,9 \\
\hline Salvador & 52.787 & 49,6 & 41.663 & 39,2 & 5.435 & 5,1 & 6.500 & 6,1 \\
\hline Barreiras & 2.654 & 50,3 & 1.984 & 37,6 & 404 & 7,7 & 235 & 4,4 \\
\hline LEM & 2.094 & 53,0 & 1.291 & 32,7 & 495 & 12,5 & 71 & 1,8 \\
\hline
\end{tabular}

Tabela 2: Componentes do déficit habitacional urbano, 2010.

Fonte: Fundação João Pinheiro, com base nos dados do Censo IBGE de 2010.

A Tabela 3 traz dados do Censo Demográfico do IBGE de 2010 - referentes ao tipo de moradia e à condição de ocupação dos domicílios - e evidencia elementos da dinâmica imobiliária nestes municípios ${ }^{13}$. Chama atenção o caso de LEM que, apesar de ter poucos anos de criação e da grande quantidade de vazios urbanos, tinha $10,5 \%$ de seus domicílios em condomínios horizontais e 7,3\% em apartamentos. Por outro lado, destaca-se o percentual de $43 \%$ dos domicílios alugados.

Evidencia-se, dessa forma, que já são adotados nesta cidade novos padrões de consumo e moradia amplamente difundidos nas últimas décadas no Brasil, em especial em cidades de porte médio e grande, associados à população das faixas de renda mais elevadas.

\footnotetext{
${ }^{13}$ De acordo com o IBGE, para o caso do tipo de ocupação dos domicílios teríamos a moradia em casa, apartamento, condomínio, cortiço ou em oca; quanto à condição de ocupação, considera-se a casa própria, cedida, alugada ou em aquisição.
} 
(Re)Estruturação Urbana e Desigualdades Socioespaciais

\begin{tabular}{|c|c|c|c|c|c|c|c|c|c|}
\hline \multirow{3}{*}{$\begin{array}{l}\text { Unidade } \\
\text { territorial }\end{array}$} & \multirow{3}{*}{$\begin{array}{c}\text { Total de } \\
\text { domicílios } \\
\text { particulares } \\
\text { permanentes } \\
\text { urbanos - } \\
\text { DPPU }\end{array}$} & \multicolumn{4}{|c|}{ Tipo de moradia } & \multicolumn{4}{|c|}{ Condição de ocupação } \\
\hline & & \multicolumn{2}{|c|}{ Condomínios } & \multicolumn{2}{|c|}{ Apartamentos } & \multicolumn{2}{|c|}{ Em aquisição } & \multicolumn{2}{|c|}{ Alugados } \\
\hline & & Total & $\begin{array}{l}\% \text { do } \\
\text { DPPU }\end{array}$ & Total & $\begin{array}{l}\% \text { do } \\
\text { DPPU }\end{array}$ & Total & $\begin{array}{l}\% \text { do } \\
\text { DPPU }\end{array}$ & Total & $\begin{array}{l}\% \text { do } \\
\text { DPPU }\end{array}$ \\
\hline Bahia & 3.034 .097 & 45.237 & 1,5 & 274.589 & 9,1 & 79.950 & 2,6 & 561.565 & 18,5 \\
\hline Salvador & 858.277 & 18.277 & 2,1 & 204.660 & 23,8 & 37.578 & 4,4 & 168.912 & 19,7 \\
\hline Barreiras & 34.824 & 137 & 0,4 & 1.605 & 4,6 & 649 & 1,9 & 8.554 & 24,6 \\
\hline LEM & 16.380 & 1.723 & 10,5 & 1.197 & 7,3 & 2.182 & 13,3 & 7.040 & 43,0 \\
\hline
\end{tabular}

Tabela 3: Tipo de moradia e condição de ocupação dos domicílios permanentes urbanos, 2010.

Fonte: IBGE, 2010.

Alguns indicadores das condições de moradia revelam também o nível de acesso às infraestruturas urbanas e aos equipamentos de uso coletivo. Para o caso das cidades estudadas, indubitavelmente, o associado ao esgotamento sanitário revela a situação dramática que vivem seus habitantes, uma vez que cerca de $90 \%$ dos domicílios em LEM e $72 \%$ em Barreiras possuíam esgotamento inadequado, como mostra a Tabela 4. São muitos os bairros nas duas cidades nos quais o esgoto corre a céu aberto, com consequências graves para a saúde da população.

$\mathrm{O}$ direito à moradia digna também é violado para aqueles que moram em domicílios cujas paredes externas encontram-se sem revestimento ou em condições precárias, feitas com materiais improvisados. Em Barreiras eram 4.240 domicílios $(12,2 \%)$ nesta condição e 1.635 domicílios (10\%) em LEM.

\begin{tabular}{|c|c|c|c|c|c|c|c|}
\hline \multirow{2}{*}{$\begin{array}{c}\text { Unidade } \\
\text { territorial }\end{array}$} & $\begin{array}{c}\text { Domicílios } \\
\text { particulares } \\
\text { permanentes } \\
\text { urbanos }- \\
\text { DPPU }\end{array}$ & \multicolumn{2}{|c|}{$\begin{array}{c}\text { Com esgotamento } \\
\text { inadequado }\end{array}$} & \multicolumn{2}{|c|}{ Sem banheiro } & \multicolumn{2}{c|}{$\begin{array}{c}\text { Com paredes externas em } \\
\text { condiçóes precárias }\end{array}$} \\
\cline { 3 - 8 } & Total & $\begin{array}{c}\text { \% do total } \\
\text { de DPPU }\end{array}$ & Total & $\begin{array}{c}\% \text { do total } \\
\text { de DPPU }\end{array}$ & Total & $\begin{array}{c}\% \text { do total } \\
\text { de DPPU }\end{array}$ \\
\hline Bahia & 3.034 .097 & 1.974 .962 & 65,1 & 324.347 & 10,7 & 355.072 & 11,7 \\
\hline Salvador & 858.277 & 59.111 & 6,9 & 3.621 & 0,4 & 85.930 & 10,0 \\
\hline Barreiras & 34.824 & 25.020 & 71,8 & 1.194 & 3,4 & 4.240 & 12,2 \\
\hline LEM & 16.380 & 14.542 & 88,8 & 135 & 0,8 & 1.635 & 10,0 \\
\hline
\end{tabular}

Tabela 4: Indicadores das condições precárias de moradia, 2010.

Fonte: IBGE, 2010.

Como revelam os números referentes às condições de moradia apresentados para Barreiras e LEM, seus crescimentos econômicos implicam no surgimento de demandas ao mercado imobiliário, assim como no acirramento das desigualdades 
sociais. Nestas cidades reconhecem-se dinâmicas espaciais que historicamente caracterizam os espaços metropolitanos. Todavia, dadas as condições insuficientes de desenvolvimento institucional e o ritmo mais intenso de crescimento demográfico e expansão urbana presentes nos municípios em estudo, os índices de precariedade tornam-se mais alarmantes. Em especial a formação de assentamentos subnormais nos últimos anos, como cortiços e favelas, que traz para estas cidades a urgência na formulação de políticas públicas destinadas a resolver tais problemas.

\section{Os agentes da produção da moradia}

Para melhor compreender como a segregação socioespacial se manifesta na cidade, inspirados nos agentes da produção do espaço urbano utilizados por Correia (1985), apresentaremos num esforço de síntese algumas dinâmicas socioespaciais que caracterizam a produção do espaço urbano em Barreiras e em LEM, as quais foram classificadas como a cidade do mercado imobiliário, a cidade informal e a cidade das políticas públicas.

\section{A cidade do mercado imobiliário}

Em primeiro lugar, ao considerarmos a cidade do mercado imobiliário enquanto aquela que reúne os agentes da produção formal da moradia (proprietários de terra, promotores imobiliários, construtoras, entre outros), é visível o forte atrelamento entre a implantação de infraestruturas e equipamentos de dimensão regional (aeroporto, parque de exposição, hotéis etc.) e as áreas residenciais voltadas à população de maior poder aquisitivo, configurando-se no que Villaça (1998) denominou como apropriação pelas elites dos investimentos públicos associados à segregação espacial.

Disso decorrem outros processos diferenciados quanto à localização dos empreendimentos imobiliários formais na cidade: por um lado, a verticalização nas proximidades do Centro, ficando grandes áreas vazias nos interstícios do espaço intraurbano, o que corresponde a um evidente processo de especulação imobiliária. Por outro, a incorporação das franjas periurbanas pelo setor imobiliário sinaliza para a tendência de autossegregação das camadas da população de renda mais alta em condomínios horizontais fechados.

No caso de Barreiras verifica-se a concentração da verticalização nos bairros pericentrais em condomínios residenciais para famílias de alta renda, como no bairro Renato Gonçalves - ao sul do Centro. Todavia, nos últimos anos passa a ocorrer o lançamento de vários loteamentos pelo setor imobiliário, situados a leste, na direção de Salvador e às margens da BR 242, como o Deltaville (ver Figura 1). 
Outra frente de expansão do setor imobiliário corresponde ao loteamento Parque da Cidade, o qual ocupa uma ampla gleba ao nordeste do Centro, entre o rio Grande e a BR 135. Juntos estes empreendimentos imobiliários agregam ao tecido da cidade extensas porções, ampliando significativamente o espaço intraurbano e, por conseguinte, a demanda por infraestrutura urbana em detrimento de partes da cidade que ainda não foram contempladas com saneamento básico.

Contudo, nem todos esses loteamentos se enquadram como zona residencial ou de ocupação prioritária, conforme estabelecido pelo Plano Diretor Urbano de Barreiras, aprovado em 2004. Ao contrário, algumas das glebas parceladas se localizam em zonas de ocupação secundária ou mesmo fora do perímetro urbano. ${ }^{14}$

Vale mencionar a inclusão neste plano de diversos instrumentos do Estatuto da Cidade, promulgado em 2001, os quais não apresentam qualquer relação direta com o zoneamento, ainda que seja possível fazer algumas suposições. Além disso, com exceção feita às zonas especiais de interesse social (ZEIS), à concessão especial para fins de moradia e ao direito de preempção, todos os demais instrumentos do Estatuto da Cidade dependem de regulamentação posterior sem que a data seja definida no Plano Diretor ${ }^{15}$. Ressalta-se, ainda, que as ZEIS adotam como lote mínimo 70 metros quadrados, enquanto que as zonas residenciais e prioritárias possuem como lote mínimo 200 metros quadrados, o que poderá permitir a regularização fundiária de assentamentos irregulares ou mesmo a implantação de conjuntos habitacionais com maior densidade demográfica.

Por sua vez, no caso de LEM merece ser destacado que a incorporação imobiliária encontra-se na origem do município, quando algumas das fazendas situadas no Chapadão começaram a ser convertidas em loteamentos e a atrair para a antiga localidade de Mimoso do Oeste - então pertencente ao município de Barreiras e que dera origem à cidade - novos moradores associados em parte às atividades do agronegócio.

Em LEM a área habitacional de médio e alto padrão conta com importantes investimentos nos últimos anos - tanto na construção de edifícios residenciais de seis, oito, dez ou mais andares ${ }^{16}$, como em condomínios horizontais de altíssimo padrão. ${ }^{17}$ Ainda que sejam pouco representativos diante do total de loteamentos com residências unifamiliares, multiplicam-se com velocidade. São cada vez mais comuns na paisagem como forma de moradia até mesmo para os empresários agrícolas que, embora proprietários de terras e com investimentos produtivos no

\footnotetext{
${ }^{14}$ De acordo com o Plano Diretor de Barreiras de 2004, ficaram estabelecidas as seguintes zonas: central, residencial, de ocupação prioritária, de ocupação secundária, de ocupação controlada, especial de interesse social e de interesse ambiental.

15 Maiores informações sobre o Plano Diretor de Barreiras podem ser obtidas na Lei $n^{\circ}$ 651/2004, de 16 de novembro de 2004, assim como nos relatórios de avaliação do Plano Diretor realizado pela Rede nacional de avaliação e capacitação para a implementação dos planos diretores participativos publicado em novembro de 2008 sob a coordenação do IPPUR/UFRJ.

${ }^{16}$ Eram mais de quinze em construção em 2014.

${ }^{17}$ Alguns contam com campo de golfe e pista de pouso para aeronaves.
} 
campo, têm na cidade seu local de residência, da mesma forma que os funcionários técnicos e executivos das grandes empresas associadas ao agronegócio ${ }^{18}$.

Essas novas formas de morar são evidências de processos de especulação e valorização imobiliária que se servem, inclusive, do imaginário social criado em torno do aumento da demanda por segurança privada em face do crescimento da violência urbana e reproduzem um padrão de segregação socioespacial na estruturação da cidade.

O grande porte dos novos loteamentos aprovados em zonas de transição urbanorural e a quantidade de lotes urbanos vazios também chama atenção em LEM e já promovem o crescimento urbano desordenado. O crescimento econômico em curso na região reforça a valorização destas áreas e traz como uma das consequências o aumento da verticalização.

Constata-se, porém, forte concentração das infraestruturas em poucos bairros, assim como dos benefícios dos serviços disponíveis nas áreas centrais e nas proximidades dos eixos viários principais. Deste modo, concentram-se os espaços da segregação residencial dos mais ricos, gravitando em torno dos bairros pericentrais.

Frente a tais processos, é possível afirmar que o Plano Diretor de LEM aprovado em 2007 requer uma revisão que o torne mais próximo da realidade local, incluindo, por exemplo, uma normatização quanto à implantação e a manutenção das redes de infraestrutura urbana pelos incorporadores que, de maneira geral, vêm ficando somente com o bônus dos processos supracitados, deixando o ônus para o poder público e para ampla parcela da população de mais baixa renda.

\section{A cidade informal}

Em referência à cidade que estamos denominando de informal e espontânea destaca-se que a mesma representa as partes da cidade ocupadas por grupos excluídos - as quais são marcadas pela ilegalidade fundiária, irregularidade urbanística, carência de infraestrutura e de serviços urbanos, precariedade habitacional e ausência de assistência técnica - que reúne, dentre outras formas de moradia precária, as áreas de ocupação (favelas), as áreas de risco, os loteamentos clandestinos e irregulares, cortiços, e até conjuntos habitacionais inacabados.

No caso da cidade informal e espontânea, embora o IBGE não tenha reconhecido nenhum aglomerado subnormal nestes municípios no Censo específico realizado em 2010, verificamos a sua presença nas duas cidades desde o

\footnotetext{
${ }^{18}$ Como em quase todo o restante da economia da região, a soja é a moeda predominante na negociação dos loteamentos e condomínios, sendo os preços fixados em sacas de soja e os grandes pagamentos programados para os períodos de safra. Ainda em 2004, quando realizamos nosso primeiro trabalho de campo na região, um prédio em Luís Eduardo Magalhães, inaugurado em 16 de julho de 2004, tinha apartamentos de $300 \mathrm{~m}^{2}$, cujo preço estava fixado em 300 mil sacas de soja.
} 
primeiro trabalho de campo, em 2004, sendo possível apontar algumas especificidades para os dois casos.

Em relação a Barreiras, considerada como cidade média, a expansão desordenada rumo às periferias garante possibilidades de ocupações irregulares para os mais pobres, em especial por meio de loteamentos clandestinos e irregulares com carências generalizadas de infraestrutura urbana (saneamento, drenagem, coleta de lixo, pavimentação etc.) e de equipamentos sociais (escolas, creches, postos de saúde etc.). As bordas destes loteamentos, assim como os espaços livres não urbanizados, conformam-se como alvos preferenciais de ocupações (favelas), sendo densamente ocupadas por moradias precárias e fazendo surgir áreas de risco em setores com maior declividade ou interrompendo linhas de drenagem natural na frente de expansão norte.

Relatos de gestores locais envolvidos com políticas públicas de enfrentamento ao problema da moradia apontam para o crescimento do número de áreas de ocupação (favelas), assim como ao adensamento das mais antigas. A verticalização e a ocupação com maior intensidade dos terrenos nas favelas melhor localizadas, dificultando ainda mais as condições de habitabilidade urbana, comprovam tal fenômeno.

Dados obtidos junto à Coordenadoria de Habitação da Secretaria de Trabalho e Promoção Social de Barreiras indicam a existência de dezoito áreas de ocupação nesta cidade, as quais correspondem a ocupações irregulares ocorridas com a anuência de antigos prefeitos. Destaque pode ser dado para o bairro Santa Luzia, com mais de 30 mil habitantes. Verdadeiro bairro-favela, ele corresponde ao maior colégio eleitoral do município. No início de 2014 sua urbanização encontrava-se em fase de projeto por meio de recurso federal do Programa de Aceleração do Crescimento (PAC).

Em LEM, o caso do bairro Santa Cruz, antes conhecido como Favela do Iraque, chama atenção pela precariedade habitacional já constatada durante nosso primeiro trabalho de campo, em 2004. Relatos dos atuais gestores apontam que mediante a doação de 1.000 lotes por parte da prefeitura, na década de 2000, esta área de ocupação teve o seu crescimento aparentemente ordenado, porém em condições insalubres, dada a falta inicial de infraestrutura urbana e à construção das moradias sem qualquer assistência técnica.

Atualmente, já na condição oficial de bairro, permanece como destino de migrantes oriundos de outras cidades, da região e de outros estados, assim como de pequenos agricultores expulsos ou expropriados com a difusão do agronegócio, na sua maioria trabalhadores em busca de oportunidades de emprego, com pouca ou nenhuma qualificação para as atividades da agricultura intensiva ou para as atividades terciárias especializadas demandadas na cidade. Tal realidade tem resultado no aumento da quantidade de moradias da mesma forma que no surgimento de cortiços para suprir as demandas habitacionais dos mais pobres, exacerbando-se a precariedade das condições habitacionais. 
Mencionadas, ocupações irregulares podem ser destacadas como fruto do acirramento das desigualdades socioespaciais trazidas com o modelo econômico hegemônico, reunindo famílias em situação de extrema pobreza e vulnerabilidade socioambiental. Poderíamos dizer, utilizando Haesbaert (1997), que dentro da cidade oficial se formam verdadeiras cidades clandestinas, mas hoje ainda mais imersas em redes ilegais de sobrevivência do que observou o autor há cerca de duas décadas.

\section{A cidade das políticas públicas}

Em relação à cidade das políticas públicas, notadamente das políticas habitacionais de interesse social, faz-se necessário reconhecer a existência de dois períodos distintos. No primeiro, desde a criação do $\mathrm{BNH}$ até os primeiros anos deste século, os programas instituídos pelos órgãos responsáveis pela produção habitacional resultaram em ações pontuais com a produção de pequenos núcleos habitacionais, os quais praticamente não tiveram impacto em Barreiras.

O segundo período se inicia na década de 2000, mais precisamente com a criação do Ministério das Cidades em 2003, quando passa a haver a realização de intervenções voltadas para remoção de áreas de ocupação em situação de risco e posterior reassentamento em pequenos conjuntos periféricos. Vale destacar as tentativas de disseminação pelo Brasil afora dos instrumentos previstos no Estatuto da Cidade voltados para promover a regularização fundiária, combater a especulação imobiliária e abrir espaço para a participação da sociedade civil nos processos de planejamento e no controle social das políticas públicas, logo nos primeiros anos deste período ${ }^{19}$.

Desde então se apostou na importância da vinculação entre as política urbana e habitacional e na revisão dos Planos Diretores municipais, segundo os conteúdos do Estatuto da Cidade. Neste sentido, se buscou viabilizar a formulação de programas habitacionais destinados às demandas específicas oriundas de áreas de risco, ocupações irregulares ou comunidades em situação de extrema vulnerabilidade social, mediante a utilização de recursos do Fundo Nacional de Habitação de Interesse Social (FNHIS) e da Resolução $460^{20}$. Para a região estudada, como exemplo mais importante se tem as intervenções realizadas no bairro Santa Cruz, em LEM.

Contudo, indubitavelmente, as políticas habitacionais de interesse social ganham novos contornos a partir de 2009 com a retomada da produção habitacional

\footnotetext{
${ }^{19}$ Maiores informações referentes a estes instrumentos podem ser obtidas na Lei ${ }^{\circ} 10.257 / 2001$, denominada Estatuto da Cidade.

${ }^{20}$ A Resolução $n^{\circ}$ 460/04, aprovada em 2004, permitiu o uso de recursos do Fundo de Garantia por Tempo de Serviço para a execução de projetos de saneamento básico, de infraestrutura urbana e habitacional, especialmente direcionados para atender famílias de baixa renda.
} 
patrocinada pelo Governo Federal, por meio do Programa Minha Casa Minha Vida (PMCMV) - a maior intervenção no setor desde o fim do Banco Nacional da Habitação (BNH), na década de 1980.

Entendemos que o PMCMV nos ajuda a melhor compreender a produção do espaço urbano e a estruturação das cidades estudadas nos últimos anos, especialmente a partir da junção das três principais formas de produção da moradia consideradas aqui como recurso metodológico: a cidade do mercado imobiliário, a cidade informal e a cidade das políticas públicas.

Dada a magnitude do programa, para entendermos a (re)estruturação das cidades, em especial as do porte das então estudadas, assim como do que estamos chamando de cidade das políticas públicas, consideramos importante apresentá-lo com maiores detalhes em seção à parte, o que faremos a seguir.

\section{O Programa Minha Casa Minha Vida}

O PMCMV tem como objetivos principais: dinamizar a economia mediante a injeção de recursos na construção civil através da produção habitacional em larga escala; e atender às famílias de baixa renda em situação de déficit habitacional. Permitiu, por sua vez, a junção de diferentes agentes da produção da moradia, uma vez que reúne o setor da construção civil - contratando recursos e realizando as obras -, a Caixa Econômica Federal (CEF) - operacionalizando o programa e controlando a utilização de recursos federais -, as instituições do poder local definindo critérios e demandas locais, assim como interferindo na escolha dos terrenos onde os empreendimentos são construídos.

No presente item tratamos da análise dos arranjos institucionais do PMCMV, da localização e das condições de inserção urbana dos conjuntos. Para tanto, baseamonos tanto na análise dos documentos inerentes ao próprio programa como nos trabalhos de campo, quando pudemos apreender, a partir da realização de entrevistas, a visão dos diferentes agentes envolvidos, em especial da gerência regional da CEF, como operadora do programa; das construtoras; do setor imobiliário local; da mesma forma que dos órgãos responsáveis pelas políticas urbana e habitacional. Somem-se a isso as visitas realizadas aos conjuntos - as quais se deram acompanhadas de gestores locais - e a posterior análise do entorno, fortalecendo a detecção e a compreensão dos problemas vinculados à inserção urbana $^{21}$.

\footnotetext{
${ }^{21}$ Vale aqui mencionar que estes estudos compartilharam de alguns elementos de análise formulados por pesquisadores integrantes da Rede de Pesquisa Cidade e Moradia, que realizou estudos sobre o PMCMV em várias cidades do país. Esta rede teve suas investigações financiadas pelo CNPq e pelo Ministério das Cidades, da qual um dos autores do presente artigo (Renato Pequeno) participa como responsável pelos estudos para a Região Metropolitana de Fortaleza.
} 
Pareceu-nos importante, antes de tudo, apresentar alguns números do programa, conforme a Tabela 5. Inicialmente, porém, destacamos que o PMCMV estabeleceu $o$ atendimento segundo diferentes faixas de renda ${ }^{22}$.

De acordo com dados obtidos no Ministério das Cidades e na CEF, para o ano de 2012 Barreiras tinha 30 contratos e LEM 27. Somavam, respectivamente, 2.199 e 1.299 unidades habitacionais (UHs). Para a cidade de Barreiras $79 \%$ das unidades contratadas eram para a faixa 1 (renda de até $\mathrm{R} \$ 1.600,00$ ), enquanto em LEM esta faixa ficava com $38,5 \%$ das unidades, com apenas 1 contrato. Em LEM predominavam as UHs para a faixa 2 (de $\mathrm{R} \$ 1601,00$ a $\mathrm{R} \$ 3.275,00$ ), com $60,5 \%$ do total (789 UHs), contra os 20,5\% (451 UHs) para Barreiras, na mesma faixa.

Em ambas as cidades o atendimento às famílias das faixas II e III, com renda entre $\mathrm{R}$ \$ 1.601,00 e R \$ 5.000,00, significa a dinamização do mercado imobiliário e da construção civil, ampliando o espectro de famílias atendidas. Dispersos em loteamentos regulares onde a produção habitacional de mercado encontra-se em franco andamento, os contratos para empreendimentos nesta faixa têm preenchido tanto pequenos vazios urbanos remanescentes em bairros próximos ao Centro, quanto nos distantes das áreas onde os conjuntos habitacionais da faixa 1 são construídos. Disto constata-se que o próprio PMCMV tem reforçado o processo de segregação, ao diferenciar os setores da cidade quanto às faixas de renda.

\begin{tabular}{|c|c|c|c|c|c|c|cr|}
\hline \multirow{2}{*}{$\begin{array}{c}\text { Unidade } \\
\text { territorial }\end{array}$} & \multicolumn{2}{|c|}{ Faixa 1} & \multicolumn{2}{c|}{ Faixa 2 } & \multicolumn{2}{c|}{ Faixa 3 } & \multicolumn{2}{c|}{ TOTAL } \\
\cline { 2 - 9 } & Contratos & UHs & Contratos & UHs & Contratos & UHs & Contratos UHs \\
\hline Barreiras & 6 & 1.738 & 19 & 451 & 5 & 10 & 30 & 2.199 \\
\hline LEM & 1 & 500 & 18 & 789 & 8 & 10 & 27 & 1.299 \\
\hline
\end{tabular}

Tabela 5: PMCMV - contratos e unidades habitacionais por faixas de renda até o final de 2012.

Fonte: Ministério das Cidades e Caixa Econômica Federal, 2012.

\section{Análise dos arranjos institucionais}

Para melhor analisar as condições como o PMCMV vem sendo implantado, é fundamental compreender seus arranjos institucionais, sobretudo o papel dos agentes operadores, do poder local, dos construtores, assim como o da aplicação das normativas do programa e dos instrumentos da política urbana e habitacional local.

A descentralização da CEF mediante a abertura de uma nova gerência regional (Gerência de Desenvolvimento Urbano) na cidade de Barreiras, em 2013, sinaliza

\footnotetext{
${ }^{22} \mathrm{O}$ PMCMV estabeleceu inicialmente as seguintes faixas de atendimento: I - famílias com renda entre 0 e 3 salários mínimos; II - famílias com renda entre 3 e 6 salários mínimos; III - famílias com renda entre 6 e 10 salários mínimos. Posteriormente as faixas foram definidas segundo valores: I famílias com renda de até $\mathrm{R}$ \$ 1.600,00; II - famílias com renda entre R\$1.601,00 e R \$ 3.275,00; III famílias com renda entre $\mathrm{R} \$ 3.275,00$ e $\mathrm{R} \$ 5.000,00$.
} 
com possibilidades para o maior dinamismo na contratação de novos empreendimentos e principalmente no controle quanto à construção e à pósocupação dos empreendimentos. Esta Gerência atende 45 municípios da região, com destaque para aqueles enquadrados no programa com população acima de 50 mil habitantes. Segundo relataram os gestores da CEF, a expectativa de ampliação do programa no curto prazo era enorme, prevendo-se a efetivação de novos contratos para Barreiras e LEM até o final de 2014, o que efetivamente se concretizou.

No que refere- se ao poder local, avanços foram percebidos no reconhecimento por parte dos gestores de que as políticas urbana e habitacional devam ser vinculadas uma à outra, assim como a necessidade de maior integração entre as secretarias envolvidas na implementação do programa no âmbito local. A existência de departamentos específicos voltados para as políticas urbana e habitacional, mesmo que por conta da maior disponibilidade de recursos federais para tais objetivos, também deve ser apontada como uma mudança positiva.

Apesar da pequena influência direta do poder local sobre o PMCMV, é possível notar diferenças na maneira como as instituições locais de Barreiras e de LEM se estruturam com vistas à implementação do mesmo. Em Barreiras, segundo informações obtidas dos gestores, o programa teve problemas na sua fase inicial, tais como: as pressões feitas por vereadores na inclusão prioritária de famílias dos seus redutos eleitorais na fase de cadastramento; a demora na definição dos beneficiários, colocando o primeiro conjunto sob o risco de invasão; a escolha de terrenos distantes do centro e desprovidos de serviços urbanos; a ausência de um plano local de habitação e a não aplicação das diretrizes urbanísticas que buscavam evitar o crescimento urbano desordenado e descontínuo previstas no Plano Diretor. Além disso, constatou-se um quadro de fragilidade institucional em Barreiras, visto que o município só veio a ter conselho e fundo municipal de habitação legalmente instituídos em 2013 e o seu Plano Local de Habitação de Interesse Social (PLHIS) só foi finalizado em 2015.

Quanto a LEM as condições de desenvolvimento institucional mostram-se mais favoráveis, uma vez que há técnicos responsáveis pela implementação da política urbana e pela política habitacional no Executivo municipal. O PLHIS, por exemplo, foi todo elaborado por técnicos da própria prefeitura, os quais destacaram durante entrevistas que LEM tem condições plenas de gestão, pois possui conselho e fundo municipal de habitação. Vale destacar, uma vez que o mais comum na última década é a não existência de tais profissionais nas prefeituras, que optam pela contratação de empresas para a realização de tais atividades.

Ainda em relação às instituições do poder local, vale dizer que para a população poder se inscrever no PMCMV em LEM o interessado deve atender a critérios localmente definidos, como a comprovação de endereço e residência de pelo menos três anos na cidade. Pareceu-nos um objetivo explícito de conter o grande 
fluxo migratório para a cidade, evitando fazer do PMCMV mais um fator de migração da região para o município.

Quanto aos construtores, ganha realce a construtora Atrium seja em Barreiras ou em LEM, que tinha hegemonia sobre as demais. Sediada em Feira de Santana (BA), esta empresa é responsável também pela realização dos equipamentos sociais complementares com vistas a contemplar as demandas dos futuros moradores e amenizar os problemas decorrentes da localização periférica e distante dos conjuntos.

Entre os aspectos positivos do PMCMV em todo o Brasil está o aumento da oferta de empregos na construção civil, que permaneceu bastante aquecida na última década. Mas, ao contrário do que se poderia imaginar, houve baixa oferta no setor para os habitantes das cidades estudadas, dada a pouca qualificação para trabalharem com a tecnologia empregada pela construtora supracitada nas obras, até então pouco utilizada na região. Desta forma, um percentual importante de trabalhadores contratados é oriundo de outros municípios como ocorre em LEM, onde somente $30 \%$ dos 300 trabalhadores atuando nos canteiros da construtora no primeiro semestre de 2014 eram originários da região.

\section{A localização dos conjuntos e as condições de inserção urbana ${ }^{23}$}

Para melhor entender as condições como o PMCMV vem sendo implantado é fundamental avaliar os empreendimentos considerando sua inserção na cidade e as relações com o entorno, segundo a distância dos equipamentos sociais, a presença de espaços livres e a mobilidade urbana. Em termos morfológicos, variáveis como a densidade demográfica e a tipologia urbanística do empreendimento também são fundamentais para a compreensão da inserção urbana dos conjuntos.

Amplamente subsidiados, os empreendimentos parcialmente entregues e em construção trazem impactos na estruturação destas cidades. No caso de Barreiras a localização periurbana, vizinha ao Distrito Industrial e distante dos primeiros conjuntos do PMCMV situados a $6 \mathrm{~km}$ do centro da cidade e a $3 \mathrm{~km}$ do bairro mais próximo, sinaliza a perversa contribuição destes ao crescimento desordenado da cidade. Além disso, tanto o público alvo passa a ter ônus da má localização no seu dia a dia, quanto o município passa a ser pressionado pela construção de equipamentos sociais e implantação de linhas de transporte.

Quanto à escolha de terrenos para a localização dos empreendimentos do PMCMV em LEM, houve, inicialmente, a possibilidade de implantação dos

\footnotetext{
${ }^{23}$ Estudos recentes promovidos em rede de pesquisa nacional avaliando o PMCMV adotaram alguns temas com vistas a classificar as principais dinâmicas que caracterizam os vínculos entre a inserção urbana e a segregação espacial. Entre estes: o direito à cidade e o acesso às redes de infraestrutura e aos serviços; a produção periférica e a abertura de novas frentes de expansão das cidades; a monofuncionalidade (PEQUENO, 2013; PEQUENO; ROSA, 2015).
} 
conjuntos em dois setores da cidade: o primeiro nas proximidades do Distrito Industrial ao oeste; o outro, em grandes vazios urbanos ao leste, nas proximidades do bairro Jardim das Oliveiras (ver Figura 1).

A implantação do primeiro empreendimento em LEM se coloca como um problema em função do terreno escolhido. Situado a mais de $11 \mathrm{~km}$ do centro da cidade e a quase $3 \mathrm{~km}$ do bairro mais próximo, o Solar dos Buritis, de acordo com a prefeitura, será alvo de programas complementares voltados a atenuar possíveis impactos das más condições de inserção urbana, como a construção de creches, escolas de Ensino Fundamental, transporte escolar e cursos profissionalizantes.

Em sua primeira etapa, foram contratadas $500 \mathrm{UHs}$, conforme consta na Tabela 4. Todavia, informações obtidas na imprensa local e confirmadas em consulta ao site da prefeitura apontam à possibilidade de contratação de outras 900 UHs numa segunda etapa em terreno vizinho. Além disso, aponta-se à possibilidade de que outros contratos de 600 e 1.800 UHs venham a ser firmados no curto prazo.

Vale aqui destacar que estes empreendimentos deverão atender às famílias do bairro mais precário próximo ao Centro, no caso, o Santa Cruz. Promove-se, com isso, o deslocamento do "problema" para a periferia. Como área detentora dos maiores índices de pobreza da cidade, a refletir as condições desiguais de desenvolvimento vigentes na região, o bairro Santa Cruz está em processo mais amplo de transformações por conta da sua localização próxima ao Centro, vizinho às grandes empresas situadas às margens das rodovias.

Uma primeira hipótese, mais otimista, seria um processo de desadensamento ao atender famílias em situação de aluguel, de coabitação ou que estejam em áreas de risco no próprio bairro. Uma segunda hipótese seria a ocorrência de um processo de deslocamento em grande escala da população, sendo a regularização fundiária em curso um caminho para a denominada "expulsão branca" ${ }^{24}$. Afinal, a proximidade com o Centro e a posição na confluência das rodovias federais garantem a esta área da cidade um valor de troca especial, principalmente para empreendimentos do setor produtivo vinculados ao agronegócio, sobretudo agroindústrias e empresas fornecedoras de produtos e serviços para a atividade agropecuária intensiva.

Chama atenção a adoção da forma condomínio como tipo urbanístico nos empreendimentos do PMCMV, assim como a utilização da casa sobreposta como tipo arquitetônico. O primeiro pela transferência do ônus de possíveis custos com segurança, iluminação dos espaços coletivos e manutenção de espaços livres para os seus futuros moradores. O segundo pela verticalização e adensamento mediante a sobreposição das unidades habitacionais, a denotar o alto custo da terra ou o aumento do lucro da empresa responsável.

\footnotetext{
${ }^{24}$ Utiliza-se a expressão expulsão branca quando a regularização fundiária de áreas irregulares visa favorecer a entrada do mercado imobiliário, o qual passa a pressionar as famílias beneficiadas com o intuito de adquirir suas casas para posterior implantação de empreendimentos mais valorizados.
} 
Alguns problemas vinculados às más condições de inserção urbana podem ser detectados no tocante à localização dos empreendimentos até aqui contratados para estes municípios. Considerando o direito à cidade, a localização em áreas onde não se tem acesso às redes de infraestrutura e nas quais os equipamentos sociais estão ausentes acaba representando a regra para os primeiros conjuntos de Barreiras e para os empreendimentos de LEM. Embora se tenha previsto a composição de matriz de responsabilidades destinada a identificar as necessidades complementares de cada empreendimento, observa-se com estes problemas a evidência maior da dissociação entre as políticas urbana e habitacional e a falta de integração entre as instituições envolvidas com o PMCMV.

Contudo, vale mencionar o caso do Residencial Boa Sorte, em Barreiras, onde a situação mostra-se mais favorável. Situado a menos de $2 \mathrm{~km}$ do Centro, este é composto por casas sobrepostas, dispensando a forma condomínio; ocupado por quase mil famílias de baixa renda, encontra-se próximo aos equipamentos e aos serviços, o que ameniza problemas de mobilidade para seus futuros moradores.

\section{Mudanças na estruturação das cidades}

Como forma de síntese, buscamos aqui reunir o conjunto de dinâmicas espaciais apresentadas visando explicitar a importância do PMCMV na estruturação das duas principais cidades que organizam a RPA associado à soja nos Cerrados nordestinos.

As figuras seguintes apresentam as considerações traçadas referentes à estruturação da cidade e à produção habitacional. A Figura 1, referente à estruturação de Barreiras, apresenta - além do eixo fortemente marcado pela BR 242 - a junção de intervenções associadas aos três principais agentes da produção habitacional. Inicialmente a cidade do mercado imobiliário - a cidade formal - pode ser caracterizada em pelo menos quatro frentes: o bairro Renato Gonçalves, marcado pela verticalização pericentral; o loteamento Parque da Cidade, próximo ao Centro e tirando proveito da proximidade à natureza, a reproduzir o ideário dos condomínios e loteamentos fechados; os loteamentos na direção de Salvador, ao longo da BR 242; e, por último, a presença de muitos pequenos empreendimentos voltados para famílias com renda entre 3 e 10 salários mínimos utilizando recursos do PMCMV, ao sudeste.

Em seguida, representando a produção informal e espontânea da moradia, destacam-se as quatro zonas de interesse social identificadas desde o Plano Diretor de 2004, constituindo-se em alvo de futuras intervenções, seja para urbanização ou para remoção e reassentamento distante.

No que tange à produção habitacional de interesse social, só recentemente ganha destaque a produção pública da moradia através de empreendimentos contratados pelo PMCMV para famílias com renda inferior a $\mathrm{R} \$ 1.600,00$. Os primeiros 
empreendimentos deste tipo, situados ao norte da mancha urbana nas proximidades do Distrito Industrial e do anel viário, são marcados pela posição periférica e pelas más condições de inserção urbana. Por sua vez, os mais recentes possuem melhor localização, em setor pericentral onde a deficiência de equipamentos sociais é menos intensa.

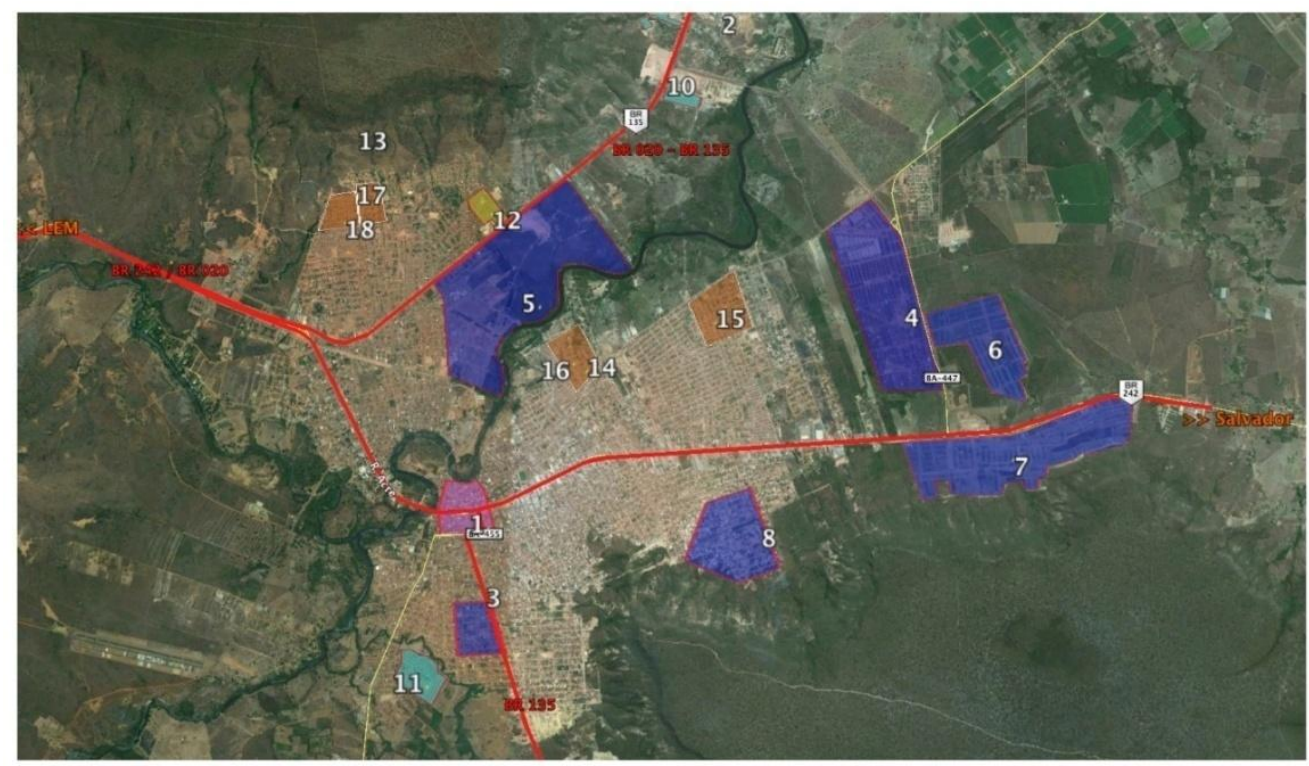

1. Centro

2. Distrito Industrial

3. bairro Renato Gonçalves

4. Loteamento Deltaville

5. Lot. Parque da Cidade

6. Loteamento
7. Loteamento

8. MCMV Faixas 2 e 3

9. MCMV Res. Barreiras I

10. MCMV Res. Barreiras II

11. MCMV Res. Boa Sorte

12. Conjunto habitacional
13. Áreas de risco

14. bairro Santa Luzia

15. ZEIS 1

16. ZEIS 2

17. ZEIS 3

18. ZEIS 4

Figura 1 - Estruturação urbana e produção habitacional na cidade de Barreiras (BA). Organizada pelos autores com base em dados coletados em trabalhos de campo.

Por sua vez, a Figura 2 expõe o processo de estruturação da cidade de LEM associado às formas de produção habitacional. Nesta cidade, apesar do crescimento até aqui compacto, as ações do mercado imobiliário formal revelam a abertura de diversas frentes multidirecionadas. A proximidade com áreas produtivas agrícolas, visível pela presença de pivôs de irrigação nas imediações da cidade, demonstra a valorização destas terras, fortalecendo a ideia de processos especulativos associados à ampla presença de lotes vagos e à emergente verticalização.

A cidade informal e espontânea mostra-se concentrada no bairro Santa Cruz, onde ocorreu a primeira ocupação irregular do município logo após a sua criação, a Favela do Iraque. Situada no cruzamento das BRs 242 e 020, esta área tem sido 
alvo de programas governamentais voltados à sua regularização, urbanização e desadensamento, por meio do deslocamento para conjuntos habitacionais distantes.

Quanto às políticas habitacionais, além das medidas pontuais implementadas no bairro Santa Cruz, evidenciam-se os empreendimentos do PMCMV. Em sua primeira fase, destaca-se um conjunto habitacional com $500 \mathrm{UHs}$, situado a $12 \mathrm{~km}$ do centro da cidade, no bairro Jardim das Oliveiras; assim como 789 UHs contratadas para as faixas 2 e 3 , distribuídas pelos diversos loteamentos da cidade. A construção de outras 900 unidades em terrenos vizinhos, já em curso, e a possível contratação de outras 1.800 UHs indicam a transformação estrutural que esta política habitacional pode trazer ao município, fazendo da segregação espacial uma característica maior da produção e da organização do espaço urbano de LEM.

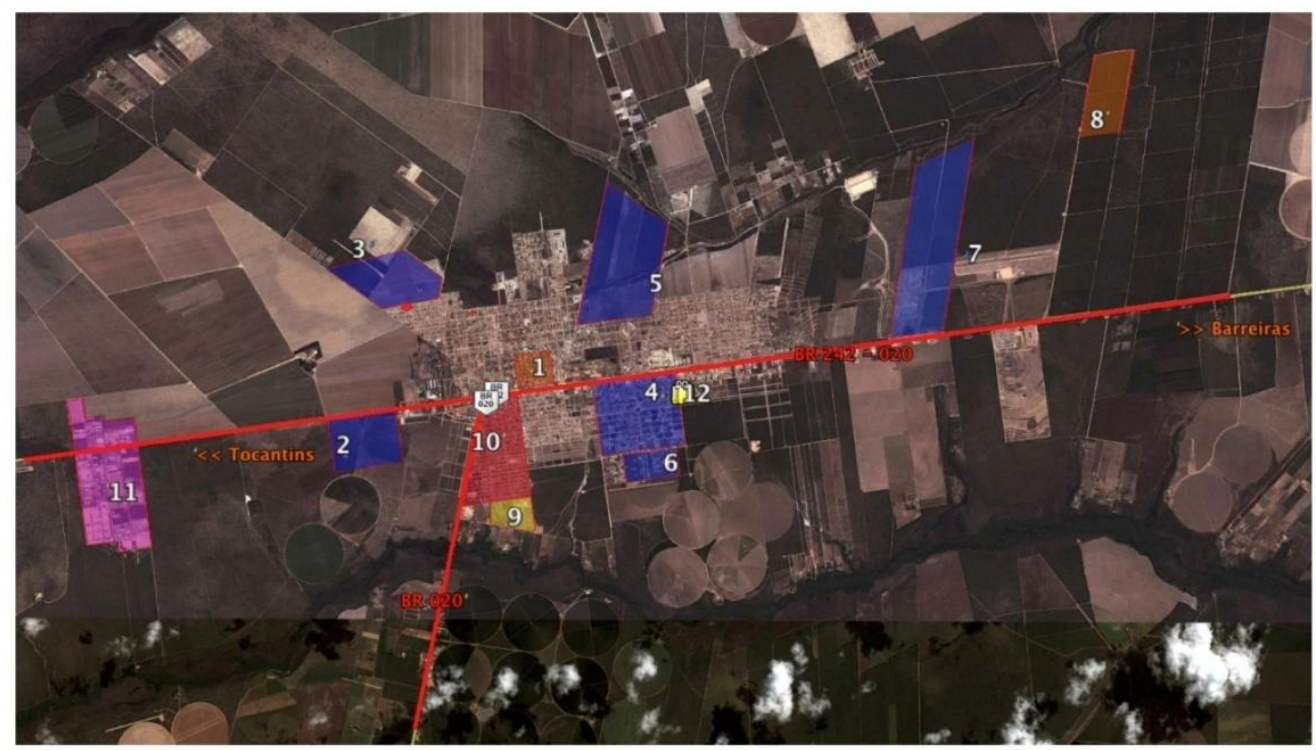
1. Centro
2. Luar do Oeste
5. Jd. Das Acácias
9. FNHIS / Res. 460
3. Luar do Cerrado
6. Cond. Fechados
10. Bairro Santa Cruz
4. Jd. Paraíso
7. Jd. das Oliveiras
8. MCMV Solar Buritis
11. Distrito Industrial
12. Shopping Center

Figura 2. Estruturação urbana e produção habitacional na cidade de Luís Eduardo Magalhães (BA).

Organizada pelos autores com base em dados coletados em trabalhos de campo

\section{Considerações Finais}

Este artigo apresentou um quadro de dinâmicas espaciais que vincula a produção e as condições de moradia às desigualdades socioespaciais nas cidades que comandam a Região produtiva do agronegócio dos Cerrados nordestinos, 
importante produtora de grãos, com destaque para Barreiras e LEM. Para melhor compreendê-las buscamos retomar algumas noções da hierarquia urbana, de modo a classificar Barreiras como uma cidade média - que historicamente comanda o oeste baiano, mas que desde a difusão do agronegócio globalizado tem sua região de influência ampliada para os estados do Piauí, do Maranhão e do Tocantins -; e a apontar LEM como uma cidade do agronegócio, representando nova centralidade urbana.

A utilização das condições de moradia como variável que viabiliza a explicitação das desigualdades socioespaciais contribuiu para a melhor compreensão do processo de estruturação dessas cidades. Para tanto, a classificação de processos que caracterizam a produção habitacional segundo seus principais agentes foi fundamental como recurso metodológico e permitiu reconhecer semelhanças e diferenças entre as duas cidades, muito embora, como destacamos, não era nosso objetivo realizar um estudo comparativo.

Cabe mencionar que o reconhecimento da estruturação das cidades apoiou-se na importância do sistema viário regional, na forma como se relaciona com a expansão da cidade e na maneira como define os usos do solo. Portanto, a posição destacada de tais cidades na rede urbana encontra-se diretamente associada à sua condição de entroncamento na região sob sua influência. Disso decorre um conjunto de decisões locacionais, tomadas tanto pelo Estado como pelo setor privado, no tocante à implantação de equipamentos que complementam e reforçam as funções assumidas por estas cidades.

Essa estrutura ganha maior nitidez à medida que se delineiam os processos associados às formas de produção da moradia, estabelecendo-se fortes vínculos entre a implantação dos empreendimentos comandados pelo setor imobiliário formal e a apropriação das melhores localizações nas cidades. Isto corrobora o macroprocesso identificado por Villaça (1998) como aquele que melhor explica o processo de estruturação das cidades brasileiras ao estudar alguns espaços metropolitanos. Evidencia-se, então, como aponta tal autor, a relevância de compreender o significado da segregação espacial nas nossas cidades, independentemente do seu porte e da sua função.

Diametralmente oposta à cidade do mercado imobiliário, a cidade informal e espontânea agrega as áreas de ocupação e as demais formas urbanas de moradia precária, cujo surgimento traz à tona o acirramento das desigualdades socioespaciais nas cidades onde o desenvolvimento desigual ganha força. Em regra, essas áreas findam por ocupar resíduos de tecido urbano pouco adequados ao uso residencial, configurando-se por vezes em situações de risco ambiental. Em outros casos, correspondem a ocupações irregulares incentivadas pelo próprio poder local, que, na ausência de condições para o enfrentamento do problema da moradia, acaba por fomentar a apropriação de terrenos desprovidos de infraestrutura urbana distantes dos equipamentos sociais. Trata-se de verdadeiros territórios de exclusão social nas cidades. 
À medida que o problema habitacional se exacerba, o Estado busca formular políticas públicas que geralmente se concentram nos espaços metropolitanos ou mesmo nas cidades de porte médio mediante a produção de conjuntos habitacionais, ainda que de maneira incompleta e pontual.

No caso de Barreiras e LEM, a realização deste trabalho propiciou visualizar a implementação de um programa habitacional, o PMCMV, o qual traz como sua principal marca a segregação residencial - como pode ser observado em todo o restante do país onde é implantado. Dessa forma, a segregação ganha novos velhos contornos, com características de segregação involuntária - onde os beneficiários dos programas habitacionais têm como bônus o acesso à casa própria desde que arquem com os ônus da localização periférica, onde o direito às benesses da cidade nem sempre é atendido. Além disso, sobressai a fragmentação do tecido sóciopolítico (SOUZA, 2001) na forma dos condomínios fechados restritos aos mais abastados e das áreas de ocupação onde predominam os mais pobres, dinâmica que evidencia o acirramento das desigualdades nas cidades estudadas.

As análises aqui empreendidas apontam à importância de que as políticas urbana e habitacional sejam associadas de modo a amenizar os problemas detectados pelas más condições de inserção urbana dos empreendimentos até aqui implantados. Outras preocupações referentes à localização dos novos conjuntos, assim como aos seus conteúdos programáticos, tendem a reduzir os desafios que as famílias deslocadas para a periferia de forma involuntária passam a enfrentar. Para tanto, faz-se necessário uma redefinição dos papéis e das atribuições dos diferentes agentes que compõem os arranjos institucionais responsáveis pela implementação de políticas e programas habitacionais de interesse social.

\section{Bibliografia}

BARREIRAS. (2004) Prefeitura Municipal. Plano Diretor Urbano - Lei no 651, de 16 de novembro de 2004. Barreiras.

CARLOS, Ana F. A. (2004) Espaço urbano. São Paulo: Contexto.

CORRÊA, Roberto L. (2006) Estudos sobre a rede urbana. Rio de Janeiro: Bertrand Brasil.

ELIAS, Denise (2013). Regiões produtivas do agronegócio: notas teóricas e metodológicas. In: BERNARDES, J. A.; SILVA, C. A. da; ARRUZZO, R. C. (orgs.). Espaço e energia. Mudanças no paradigma sucroenergético. Rio de Janeiro: Lamparina. pp. 201-220.

(2011) Agronegócio e novas regionalizações no Brasil. Revista Brasileira de Estudos Urbanos e Regionais (ANPUR), v.13, nº 2. pp.153-167.

(2010) O Brasil agrícola com áreas urbanas: a cidade do agronegócio.

In: OLIVEIRA, J. A. (org.). Cidades brasileiras: territorialidades, sustentabilidade e demandas sociais. Manaus: Ed. da UFAM. pp.147-164. 
(2007) Agricultura e produção dos espaços urbanos não metropolitanos: notas teórico-metodológicas. In: SPOSITO, M. E. (org.). Cidades médias: espaços em transição. São Paulo: Expressão Popular (Coleção Geografia em Movimento). pp. 113-138.

. (2006a) Novas dinâmicas territoriais no Brasil agrícola. In: SPOSITO, E. S.; SPOSITO, M. Encarnação; SOBARZO, Oscar (orgs.). Cidades médias: produção do espaço urbano e regional. São Paulo: Expressão Popular, v. 1. pp. 279-303.

(2006b) Globalização e fragmentação do espaço agrícola do Brasil. Scripta Nova. Barcelona / Espanha, v. 1. pp. 59-81.

(2006c) Ensaios sobre os espaços agrícolas de exclusão. Revista NERA (UNESP), v. 1, no 8 . Presidente Prudente (SP). pp. 29-51.

. (2003); Globalização e Agricultura. São Paulo: EDUSP.

ELIAS, D.; PEQUENO, R. (2007) Desigualdades socioespaciais nas cidades do agronegócio. Revista Brasileira de Estudos Urbanos e Regionais, v.9, nº1.

(2006) Difusão do agronegócio e novas dinâmicas socioespaciais. Fortaleza: Banco do Nordeste/Etene.

. (2005) Espaço urbano no Brasil agrícola moderno e desigualdades socioespaciais. Terra Livre, $\mathrm{n}^{\circ} 25$. pp.13-33.

FUNDAÇÃO JOÃO PINHEIRO. (2014) Déficit habitacional no Brasil 20112012: resultados preliminares / Fundação João Pinheiro (Nota técnica, 1). Centro de Estatística e Informação. Belo Horizonte.

(2013) Centro de Estatística e Informações. Déficit habitacional municipal no Brasil. Fundação João Pinheiro. Centro de Estatística e Informações. Belo Horizonte.

HAESBAERT, R. (1997) Des-territorialização e identidade: a rede "gaúcha" no Nordeste. Niterói: EdUFF.

IBGE. Censo Demográfico 2010. Rio de Janeiro: IBGE.

LUIS EDUARDO MAGALHÃES. (2007) Prefeitura Municipal. Plano Diretor Urbano - Lei n²55, de 14 de junho de 2007. Luis Eduardo Magalhães.

PEQUENO, R. (2013) Minha Casa Minha Vida em Fortaleza: novas periferias. In: Anais do XV ENANPUR - Desenvolvimento, planejamento e governança. Recife.

. (2010) Condição de moradia: retrato das desigualdades socioespaciais. In: OLIVEIRA, J. A. (org.) Cidades Brasileiras: territorialidades, sustentabilidade e demandas sociais. Manaus: Ed. da UFAM. pp. 40-56.

; ELIAS, D. (2010) Tendências da urbanização e espaços urbanos não metropolitanos. Cadernos Metrópoles, v. 12, nº 24, jul./dez. pp.441-465.

; ROSA, S. V. (2015) Inserção urbana e segregação espacial: análise do Programa Minha Casa Minha Vida em Fortaleza. In: Anais do XVI ENANPUR Espaço, planejamento e insurgências. Belo Horizonte.

SANTOS, M. (1993) A urbanização brasileira. São Paulo: Hucitec. . (1988) Metamorfoses do espaço habitado. São Paulo: Hucitec. 
. (1985) Espaço e método. São Paulo: Nobel.

SANTOS FILHO, M.; FERNANDES, A. (1988) A Modernização do campo nos cerrados baianos. Espaço e Debates, ano VIII, n 25 . pp. 63-75.

SPOSITO, M. E. (2010a) Novas redes urbanas: cidades médias e pequenas no processo de globalização. Revista de Geografia, São Paulo, v. 35. pp. 51-62.

. (2010b). Formas espaciais e papéis urbanos: as novas qualidades da cidade e do urbano. Cidades. Presidente Prudente, v. 7. pp. 125-147.

VILLAÇA, F. (1998) Espaço intra-urbano no Brasil. São Paulo: Nobel. 